\title{
Pendekatan Komunikasi Antarpribadi Guru Dalam Menangani Siswa Bermasalah (Studi Hubungan Guru dan Siswa di SMK Negeri 1 Jakarta)
}

\author{
Novianti Lorensia, Yugih Setyanto \\ lorensianovianti@gmail.com,yugihs@fikom.untar.ac.id \\ Fakultas Ilmu Komunikasi Universitas Tarumanagara
}

\begin{abstract}
This research dicusses interpersonal communication between teachers and troubled students at SMKN 1 Jakarta. Basically, communication starts from family environment. Communication also occurs in learning process at school. Oftentimes, failures encountered in communication process are commonly caused by weak communications. Therefore, it can create or cause various problems for students, namely issues or brawls and "victims" of seniority. Of these problems can establish more personal relationship between teachers and students. This research uses theories consisting of communication theory, interpersonal communication, psychological communication, problematic students analysis and adolescence analysis. The research was conducted using descriptive qualitative research through case study research methods. From this research, it can be seen that interpersonal communication between teachers and students in the learning process in classroom to provide understanding to students is already good enough, communications that occurs directly in SMK Negeri 1 Jakarta is all directions communication, not only involves interaction between teachers and students, but also involves interaction among students, and interpersonal communication approach conducted by teachers to troubled students using spiritual approach or religious approach.
\end{abstract}

Keywords: Interpersonal communication, troubled students, adolescence.

\begin{abstract}
Abstrak
Penelitian ini membahas mengenai pendekatan komunikasi antar pribadi guru dan siswa bermasalah di SMKN 1 Jakarta. Pada dasarnya komunikasi berawal dari lingkungan keluarga. Komunikasi juga dapat terjadi dalam proses belajar mengajar di lingkungan sekolah. Seringkali, dalam proses komunikasi ditemui kegagalan yang biasanya disebabkan oleh lemahnya komunikasi. Oleh karena itu, dapat menimbulkan berbagai masalah bagi kalangan siswa yaitu masalah tawuran dan "korban" dari senioritas. Penelitian ini menggunakan sejumlah konsep terdiri dari teori komunikasi, komunikasi antar pribadi, komunikasi pendidikan, psikologi komunikasi. Penelitian ini menganalisis siswa bermasalah dan masa remaja. Penelitian dilakukan dengan pendekatan penelitian kualitatif deskriptif melalui metode penelitian studi kasus. Dari penelitian ini dapat diketahui bahwa komunikasi antar pribadi antara guru dan siswa dalam proses pembelajaran di kelas untuk memberikan pemahaman kepada siswa sudah cukup baik. Komunikasi yang terjadi secara langsung di SMK Negeri 1 Jakarta adalah komunikasi semua arah, tidak hanya melibatkan interaksi antara guru dengan siswa tetapi melibatkan interaksi antara siswa dengan siswa lainnya. Pendekatan komunikasi antar pribadi yang dilakukan oleh guru kepada siswa yang memiliki masalah menggunakan pendekatan agama.
\end{abstract}

Kata Kunci: Komunikasi antar pribadi, siswa bermasalah, masa remaja 


\section{Pendahuluan}

Dalam kehidupan sehari-hari, semua orang pastinya melakukan komunikasi dengan orang lain. Berawal dari berbicara, menulis surat, dan menelpon itu semua termasuk ke dalam komunikasi. Pada dasarnya komunikasi berawal dari lingkungan keluarga, sebab keluarga merupakan kelompok terkecil dan terdekat. Komunikasi dalam keluarga terbentuk dengan adanya interaksi orangtua dan anak, sehingga jika komunikasi berjalan dengan baik maka dengan mudahnya orangtua dapat mengawasi setiap perkembangan anak, sedangkan anak dapat mematuhi peraturan yang diterapkan oleh orangtua dalam keluarga.

Komunikasi juga dapat terjadi di lingkungan sekolah. Lingkungan sekolah ini merupakan lingkungan kedua yang sangat berpengaruh dalam pembentukan komunikasi itu sendiri. Seringkali dalam proses pendidikan di sekolah, kita temui kegagalan seperti lemahnya komunikasi. Naim (2011) mengungkapkan bahwa komunikasi pendidikan yaitu suatu proses penyampaian pesan yang merambah bidang pendidikan, dan berperan penting untuk menyampaikan informasi mengenai ilmu pengetahuan dan bertujuan memperlancar kegiatan belajar dari guru kepada siswa.

Komunikasi itu sangatlah penting, namun lingkungan tempat tinggal kita melakukan komunikasi tidak kalah pentingnya. Lingkungan yang buruk akan memiliki potensi merusak kebiasaan yang baik, sehingga akan berpengaruh pada pola pikir dan tindakan seseorang. Kemajuan teknologi yang semakin canggih, akan mengubah tingkah laku seseorang, dimana individu lebih bersikap individual.

Sekolah Menegah Kejuruan Negeri 1 (SMKN 1) merupakan sebuah sekolah kejuruan teknik tertua di antara sekolah kejuruan teknik yang ada di Jakarta. SMKN 1 Jakarta ini didirikan pada tahun 1906 oleh Belanda dan diberi nama "KONING KLIKE WILHELMINA SCHOOL" atau disingkat dengan KWS. Sekolah ini didirikan dengan tujuan mendidik siswa-siswa Belanda dan siswi pribumi pilihan yang dipersiapkan sebagai tenaga teknik dalam rangka membangun negara Hindia Belanda. Sekolah ini juga banyak menghasilkan para alumni yang berhasil (www.smknljakarta.sch.id diunduh pada tanggal 17 September 2018 pada jam 17.22 WIB).

SMK Negeri 1 Jakarta yang terletak di jalan Budi Utomo No. 7, Kel. Pasar Baru, Kecamatan Sawah Besar, Jakarta Pusat 10710 merupakan salah satu sekolah di Jakarta yang sempat dikenal sebagai biang tawuran antar pelajar ( https://www.republika.co.id/berita/nasional/umum/12/09/27/mb0eok-ini-dia-kiatsmk-budi-utomo-tekan-tawuran diakses pada tanggal 28 November 2018 pukul 18.00 WIB).

Permasalahan yang dihadapi siswa ini dapat diselesaikan dengan menggunakan komunikasi antar pribadi antara guru dan siswa. Komunikasi antarpribadi disebut juga dengan komunikasi interpersonal bertujuan untuk mengelola hubungan bahkan pada pembentukan konsep diri dan pengembangan kepribadian yang baik (Mulyana, 2005).

Selain itu, fungsi komunikasi antarpribadi yang dilakukan guru untuk menjembatani penyelesaian permasalahan yang sering dihadapi oleh siswa adalah fungsi to-educate (Effendy, 2006). Para guru seharusnya memiliki fungsi to-educate sehingga apapun yang mereka lakukan saat di lingkungan sekolah dapat berdampak positif kepada siswanya. 
Berdasarkan uraian di atas, maka penulis tertarik untuk melakukan penelitian dengan judul "Pendekatan Komunikasi Antar Pribadi Guru Dalam Menangani Siswa Bermasalah (Studi Hubungan Guru dan Siswa di SMK Negeri 1 Jakarta)" mengenai komunikasi antarpribadi guru dan siswa bermasalah di SMKN 1 Jakarta untuk mengetahui bagaimana pendekatan komunikasi antarpribadi guru dalam menangani siswa bermasalah di SMKN 1 Jakarta.

Ruang lingkup dalam penelitian ini lebih tertuju pada siswa yang memiliki masalah tawuran dan menjadi "korban" senioritas kakak kelasnya di SMK Negeri 1 Jakarta.

Gambar 1. Kerangka Pemikiran

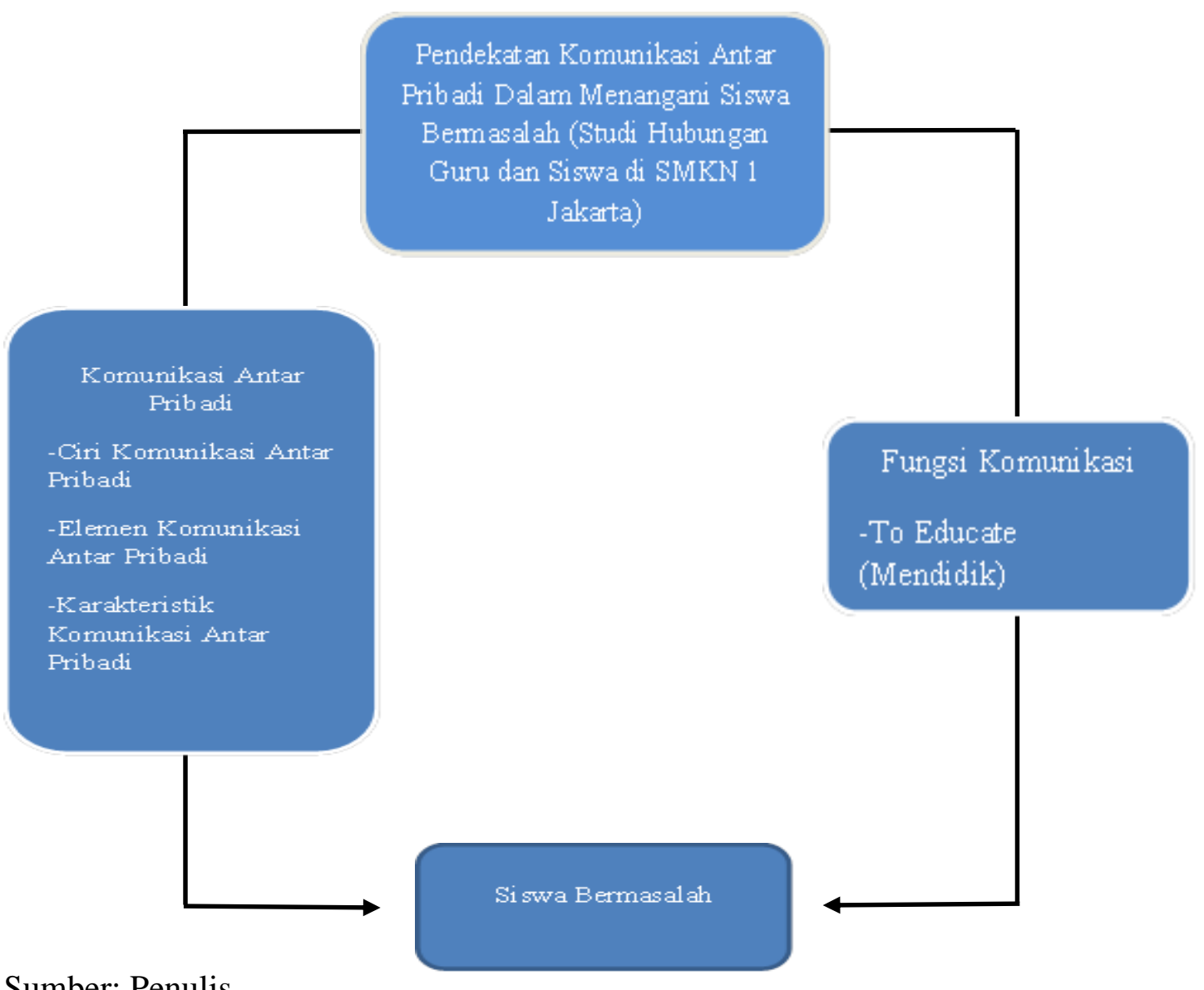

Sumber: Penulis

Gambar 1 merupakan kerangka pemikiran yang penulis gunakan dalam penelitian ini yaitu bagaimana pendekatan komunikasi antarpribadi guru dalam menangani siswa bermasalah di SMK Negeri 1 Jakarta.

\section{Metode Penelitian}

Dalam penelitian ini penulis melakukan penelitian menggunakan pendekatan kualitatif dengan metode penelitian studi kasus. Teori merupakan alat utama dalam melakukan penelitian mulai dari memilih dan menemukan masalah, membangun hipotesis, sampai dengan proses pengujian data atau analisis data. Untuk memperkuat data penelitian maka penulis menggunakan metode pengumpulan data 
dengan melakukan wawancara secara mendalam, observasi atau pengamatan, studi kepustakaan, dan penelusuran data online. Narasumber dalam penelitian ini, sebagai berikut:

a. Narasumber pertama adalah Indah Zakiah selaku guru BK khususnya untuk siswa kelas 11 di SMKN 1 Jakarta yang bertugas untuk memantau dan mengawasi perkembangan siswa di sekolah maupun diluar sekolah, serta membina dan mendidik siswa yang memiliki masalah bertentangan dengan aturan sekolah.

b. Yang kedua adalah Udin Komarudin selaku guru dan wali kelas, khususnya wali kelas siswa "RA". Bertugas untuk mengawasi dan memantau perkembangan siswa di sekolah, serta memberikan masukan positif kepada siswa agar menjadi pribadi yang baik.

c. Yang ketiga adalah siswa inisial "RA" beserta orangtuanya merupakan siswa kelas XI TKR 1 memiliki masalah tawuran dengan sekolah lain. Selain itu, pihak sekolah telah memberikan surat peringatan kedua kalinya kepada siswa tersebut dengan permasalahan yang bertentangan dengan aturan sekolah.

d. Yang keempat adalah siswa inisial "AZS" beserta orangtuanya merupakan siswa kelas XI DPIB 3 memiliki masalah tawuran. Selain itu, pihak sekolah telah memberikan surat peringatan kedua kalinya kepada siswa tersebut dengan permasalahan yang bertentangan dengan aturan sekolah.

e. Yang kelima adalah Melisa Florentina selaku pakar Psikolog Komunikasi dan Dosen Fakultas Ilmu Komunikasi Universitas Tarumanagara yang memiliki pengetahuan mengenai konsep karakter remaja serta siswa bermasalah.

Dalam penelitian ini, teknik analisis data, pertama mengumpulkan data, melakukan wawancara dengan informan dan melakukan observasi. Kedua, melakukan reduksi data dengan memilah-milah data yang diperoleh di lapangan. Ketiga, menyajikan data yang telah disederhanakan dan tersusun, memungkinkan penulis untuk melakukan tindakan penarikan kesimpulan. Terakhir, melakukan verifikasi dan penarikan kesimpulan (Moleong, 2009).

\section{Hasil Temuan dan Diskusi}

Lingkungan keluarga merupakan asal mula tempat orang melakukan komunikasi dengan orang lain. Lingkungan keluarga juga melibatkan peran orangtua untuk memantau dan sebagai pengawas perkembangan perilaku anaknya. Seperti yang kita ketahui, bahwa latar belakang siswa melakukan aktivitas sehari-hari tentu dalam pemantauan orangtua, bagaimana orangtua mendidik mereka dan bagaimana orangtua sangat berdampak pada perilaku-perilaku mereka saat berada di lingkungan sekolah.

Berdasarkan hasil wawancara yang dilakukan terdapat berbagai strategi yang dilakukan oleh orangtua untuk membangun hubungan dengan anak sewaktu mereka berada didalam lingkungan keluarga. Orang tua siswa inisial "RA" mengatakan bahwa selalu berkomunikasi dan selalu bertanya kegiatan apa yang anaknya kerjakan, baik dilakukan di sekolah maupun diluar sekolah. Strategi lain juga dilakukan oleh orangtua siswa inisial "AZS" mengatakan bahwa berbicara 
selayaknya sebagai teman agar anak tidak terlalu tegang dan selalu memberikan motivasi yang positif.

Komunikasi juga dapat terjadi di lingkungan sekolah. Lingkungan sekolah juga berpengaruh dalam proses pembentukan komunikasi itu sendiri. Setiap aktivitas sekolah memerlukan dan membutuhkan komunikasi baik antara guru dengan siswa ataupun siswa dengan guru, yang akan dibahas oleh penulis adalah komunikasi guru di lingkungan sekolah dalam menangani siswa yang memiliki masalah dengan berfokus kepada komunikasi antar pribadi karena teori komunikasi tersebut yang paling sering terjadi dalam lingkungan sekolah. Komunikasi yang terjalin antara guru dan siswa di SMK Negeri 1 Jakarta memiliki ciri khas tersendiri karena mempunyai norma-norma yang tidak tertulis dan sesuai dengan aturan yang telah disepakati oleh pihak sekolah.

Menurut Effendy (2013) menyatakan bahwa pendidikan merupakan sebuah proses yang melibatkan dua komponen yang terdiri dari pengajar sebagai komunikator dan pelajar sebagai komunikan. Menurut hasil wawancara yang dilakukan dengan salah satu pakar psikolog komunikasi yaitu Melisa Florentina mengatakan bahwa saat ini proses komunikasi di lingkungan sekolah terhubung dengan salah satu bagian dari pihak sekolah yaitu bagian bimbingan konseling dengan tujuan yaitu guru BK mencoba untuk membimbing anak-anak yang punya masalah, sehingga tumpuannya ada di guru BK, wali kelas dan teman-temannya.

Sementara menurut Indah Zakiah selaku guru BK SMK Negeri 1 Jakarta mengatakan bahwa menjadi seorang guru BK tentunya memiliki hambatan seperti sulitnya untuk berkomunikasi dengan orangtua siswa. Kemudian juga siswa sendiri merupakan tantangan buat guru BK maupun guru lain jika siswa tersebut tipe orangnya tidak terbuka. Dalam penelitian ini, penulis tidak hanya berfokus pada guru BK, namun juga pada guru wali kelas.

Melihat wawancara yang dilakukan dengan siswa inisial "RA" merupakan siswa kelas 11 TKR 1 memiliki masalah tawuran dan telah diberikan surat peringatan kedua kalinya dari pihak sekolah. Saat ini siswa "RA" sedang dalam penanganan konseling dengan setiap harinya membuat absen pada saat jam masuk sekolah pukul berapa dan saat pulang sekolah pukul berapa. Selain itu, datang ke sekolah diharuskan lebih pagi dari teman lainnya dan datang sekolah ataupun pulang sekolah harus diantar dan dijemput oleh orangtua. Hal yang sama juga dirasakan oleh narasumber siswa inisial "AZS" merupakan siswa kelas 11 DPIB 3 memiliki masalah tawuran dengan siswa sekolah lain dan menjadi "korban" senioritas.

Siswa yang melakukan aksi tawuran dengan siswa sekolah lain bertujuan untuk membela nama baik sekolah dan juga kedekatan dengan teman sebaya dalam suatu geng sangat berpengaruh dalam proses pembentukan komunikasi. Oleh karena itu, siswa yang memiliki masalah belum terbuka untuk mengkomunikasikan masalahnya kepada guru dan oranglain, khususnya orangtua.

Dengan kemajuan teknologi yang semakin canggih, maka guru yang bertugas untuk menangani siswa yang bersangkutan membuat sebuh grup WhatApps sehingga dapat terhubung dengan siswa, orangtua siswa, dan guru lainnya. Indah Zakiah selaku guru BK mengatakan bahwa selalu koordinasi dengan tim kesiswaan yang berkaitan dengan perkumpulan siswa. Tim kesiswaan biasanya ada tim swipping. Pada saat pulang sekolah, tim swipping ini menyebar memantau siswa-siwa yang masih mungkin tidak langsung pulang, biasanya nongkrong dulu atau mampir kemana dulu. Biasanya tim kesiswaan itu memotret siswa yang bertentangan dengan 
aturan sekolah terus diinformasikan ke guru BK, selanjutnya diproses dan kemudian koordinasi dengan wali kelas.

Dalam komunikasi antara guru dan siswa membentuk kedekatan antara guru dan siswa. Hal ini dibuktikan berdasarkan hasil wawancara yang dilakukan dengan siswa inisial "RA" mengatakan bahwa hubungan antara dirinya dengan Indah Zakiah selaku guru BK dapat dikatakan dekat. Meskipun tidak pernah bercerita kalau soal yang sedih, ceritanya tentang yang senang. Hal yang sama juga dirasakan oleh siswa inisial "AZS".

Dalam berkomunikasi antara guru dan siswa mengandung nilai moral yang positif. Akan tetapi terdapat beragam respon yang ditunjukkan oleh para siswa seperti halnya yang ditunjukkan oleh salah satu siswa yang menjadi narasumber penelitian yaitu siswa inisial "AZS" mengatakan bahwa dirinya mau nurut dengan masukan yang diberikan oleh guru tetapi susah dijalankan terkadang masih memikir bahwa dirinya masih ada rasa ingin bersama temannya dan menikmati masa muda.

Pace dan Cangara (2007) mengemukakan teori komunikasi adalah "interpersonal communication is communication involving two or more people in a face to face setting." Dari penjelasan tersebut terlihat bahwa dalam menyelesaikan suatu permasalahan yang dihadapi siswa, maka seorang guru membutuhkan komunikasi secara intim yang sifatnya lebih personal atau pribadi kepada siswa yang sedang ditanganinya.

Pendekatan komunikasi antarpribadi yang dilakukan oleh Indah Zakiah selaku guru BK saat berkomunikasi dengan siswa "RA" menggunakan pendekatan agama. Indah Zakiah mengatakan selalu berusaha untuk siswa melaksanakan tanggung jawab dia sebagai makhluk Tuhan. Meningkatkan pendekatan dia dengan yang Maha. Oleh karena itu, pendekatan agama selalu menjadi poin penting.

Hal yang sama juga dirasakan oleh narasumber Udin Komarudin selaku guru dan wali kelas siswa inisial "RA" mengatakan bahwa pendekatan komunikasi agar siswa dapat berubah tentunya dengan pendekatan spiritual. Kita sebagai Makhluk Tuhan diciptakan oleh Tuhan Yang Maha Kuasa, Maha Melihat, sehingga setiap perilaku kita tidak terlepas dari pengawasan yang Maha Kuasa. Pendekatan agama ini sesuai dengan anjuran dari agama masing-masing.

Menurut Guru BK Indah Zakiah, terdapat perkumpulan yang menjadi pemicu siswa bermasalah. Perkumpulan ini merupakan suatu kumpulan perjurusan daerah tempat tinggal timur, barat, selatan maupun utara. Pemicu permasalahan terjadi dikarenakan sistem perkumpulan tersebut yang mendorong terjadinya perkumpulan antar siswa dengan daerah tempat tinggal yang sama. Adanya perkumpulan tersebut menimbulkan "rasa tidak suka" dari siswa sekolah lain kepada siswa SMKN 1 Jakarta.

Selain itu, komunikasi yang efektif untuk menyelesaikan suatu permasalahan dengan menggunakan fungsi komunikasi to-educate (Effendy, 2006). Para guru seharusnya menerapkan fungsi komunikasi to-educate sehingga apapun yang mereka lakukan dapat berdampak positif kepada siswanya. Keberhasilan komunikasi di lingkungan sekolah dikatakan berhasil jika menerapkan fungsi to-educate dalam melaksanakan proses komunikasi itu sendiri.

\section{Simpulan}

Berdasarkan uraian hasil temuan dan pembahasan yang telah dipaparkan, maka dapat disimpulkan beberapa hal yang berkaitan dengan pendekatan komunikasi 
antarpribadi guru dalam menangani siswa bermasalah, sebagai berikut: Komunikasi antar pribadi antara guru dan siswa dalam proses pembelajaran di kelas untuk memberikan pemahaman kepada siswa sudah cukup baik. Komunikasi antara guru dan siswa terjadi secara langsung dengan tatap muka, tidak hanya terjadi dalam proses pembelajaran tetapi juga terjadi di luar jam pembelajaran maupun diluar lingkungan sekolah; guru melakukan komunikasi antar pribadi dengan siswa dalam hal menyampaikan materi pembelajaran, membimbing siswa, memberikan motivasi yang positif kepada siswa, meningkatkan pengetahuan dan informasi kepada siswa, serta memberikan contoh perilaku dan kepribadian yang baik kepada siswa; Komunikasi antar pribadi antara guru dan siswa mempunyai lima ciri agar berjalan dengan efektif yaitu keterbukaan, empati, sikap positif, kesetaraan, dan sikap mendukung; Komunikasi yang terjadi secara langsung di SMK Negeri 1 Jakarta adalah komunikasi yang tidak hanya melibatkan interaksi antara guru dengan siswa tetapi juga antar siswa; Pendekatan Komunikasi Antar Pribadi yang dilakukan menggunakan pendekatan spiritual atau pendekatan agama; Salah satu pemicu tawuran adalah adanya perkumpulan siswa berdasarkan tempat tinggal. Siswa yang bertempat tinggal satu wilayah sering terjadi pergesekan antara siswa sekolah lain dikarenakan perbedaan pendapat antara sekolah; Siswa yang memiliki masalah masih belum terbuka untuk mengkomunikasikan masalahnya kepada guru dan oranglain.

\section{Ucapan Terima Kasih}

Penulis mengucapkan terimakasih kepada seluruh narasumber (tujuh orang) dan sahabat penulis selama masa perkuliahan yang telah bersedia dan memberikan kerjasama selama proses penelitian berlangsung.

\section{Daftar Pustaka}

Effendy, Onong Uchyana. (2006). Ilmu Komunikasi Teori dan Praktek. Bandung: Citra Aditya Bakti

Effendy, Onong Uchyana. (2013). Ilmu Komunikasi Teori dan Praktek. Bandung: PT. Remaja Rosdakarya

Harapan, Edi. H. Syarwani Ahmad. (2014). Komunikasi Antarpribadi: Perilaku Insani dalam Organisasi Pendidikan. Jakarta: PT. RajaGrafindo Persada

Mulyana, Deddy. (2005). Human Communication: Prinsip-Prinsip Dasar. Bandung: PT. Remaja Rosdakarya

Naim, Ngainum. (2011). Dasar-dasar Komunikasi Pendidikan. Yogyakarta: Ar-Ruzz Media

Setiawan, C., \& Azeharie, S. (2017). Studi Komunikasi Antarpribadi Anak Dengan Orang Tua Tiri. Jurnal Komunikasi, 9(1), 74-80. Retrieved from https://journal.untar.ac.id/index.php/komunikasi/article/view/79/646

https://www.republika.co.id/berita/nasional/umum/12/09/27/mb0eok-ini-dia-kiatsmk-budi-utomo-tekan-tawuran diakses pada tanggal 28 November 2018 pukul $18.00 \mathrm{WIB}$

www.smknljakarta.sch.id diunduh pada tanggal 17 September 2018 pada jam 17.22 WIB 